\title{
Factors that influence patients' views on treatment decision-making in localised kidney cancer
}

\author{
Katharina Beyer ${ }^{1}$, Ravi Barod ${ }^{2}$, David Nicol ${ }^{3}$, Muddassar Hussain $^{4}$, Mieke Van Hemelrijck ${ }^{1}$, Netty Kinsella ${ }^{1,3}$ \\ ${ }^{1}$ King's College London, Faculty of Life Sciences and Medicine, Translational and Oncology Research (TOUR), London, UK; ${ }^{2}$ Specialist Centre for \\ Kidney Cancer, Royal Free Hospital, London, UK; ${ }^{3}$ Department of Urology, Royal Marsden Hospital, UK; ${ }^{4}$ Department of Urology, Frimley Health \\ NHS Foundation Trust, Surrey, UK \\ Correspondence to: Katharina Beyer. Translational Oncology and Urology Research (TOUR), School of Cancer and Pharmaceutical Studies, 3rd Floor, \\ Bermondsey Wing, Guy's Hospital, Great Maze Pond, London SE1 9RT, UK. Email: katharina.beyer@kcl.ac.uk.
}

Submitted Oct 07, 2020. Accepted for publication Oct 19, 2020.

doi: $10.21037 /$ tau-20-1317

View this article at: http://dx.doi.org/10.21037/tau-20-1317

The increasing number of treatment options for localised kidney cancer presents a unique challenge for both patients and clinicians during the decision-making process (1). Current treatment options for localised tumours (T1b, T2, T3), which comprise the largest group of patients, include active surveillance, surgery and minimally invasive ablative procedures $(1,2)$. These differ with respect to morbidity and individual patient confidence with respect to long term outcomes and potential implications.

International guidelines on treatment decision-making in cancer-care recognise the importance of involving patients in the treatment decision-making process (3). The American Urological Association and the NICE guidelines in the UK highlight that treatment decisions are 'preference sensitive' and recommend implementing shared decision-making $(1,4)$. In order to implement this, it is first important to understand what factors influence a patient's decisionmaking.

We conducted a systematic review of the evidence following the Preferred Reporting Items for Systematic Reviews and Meta-Analysis (PRISMA) guidelines (5). A computerised literature search of databases (PubMed, Cochrane) was performed to identify full text and abstracts published between 1st of January 2004 to September 2020 (Figure 1). Studies were selected on the basis that: (I) they explored patient views on treatment decision-making; (II) they were of sufficient methodological quality; and (III) their findings could be translated into suggestions for supportive care.

After screening titles and abstracts we identified 534 studies of which 22 met the inclusion criteria. Full text review of these by two authors (NK and $\mathrm{KB}$ ) five studies were identified as relevant (Figure 2). Data was extracted following a Bayesian approach where data is codified into themes and presented in a meta-aggregation generating summative statements of the evidence (6). For each identified study we extracted information on treatment decision-making factors identified by patients.

One study evaluated an interdisciplinary service for renal malignancies (7), whereas another conducted an assessment of patients'/caregivers' perception of information provided in renal cancer treatment (8). The third study used a survey to measure the patients' decisional quality (e.g., emotional impact or knowledge of the decision to take) in patients diagnosed with localised kidney cancer (1). The fourth and fifth study developed a patient decision aid for surgical treatment and active surveillance in localised renal cancer (9).

A summary of the factors identified to influence patient decision-making in these five studies is shown in Table 1. Key themes emerged around 'Patient-related criteria' and 'Patient-physician interaction'. The patient-related criteria included: decisional quality and patient's risk perception (e.g., anxiety, concerns about cancer) (1,7-9). Factors contributing to the patient-physician interaction centred around patient involvement in decision-making, perceived shared decision-making and the negative influence of paternalistic care $(1,7,8)$.

The five studies also identified gaps in supportive care during the decision-making process and recommended a move away from a paternalistic decision making model. Shirk 
Table 1 Summary table: factors influencing patient decision-making

\begin{tabular}{|c|c|c|c|c|}
\hline $\begin{array}{l}\text { Decision maker } \\
\text { criteria }\end{array}$ & Factors & $\begin{array}{l}\text { Supportive care } \\
\text { suggestions }\end{array}$ & $\begin{array}{l}\text { Why is this important in clinical } \\
\text { practice }\end{array}$ & Ref \\
\hline \multirow[t]{2}{*}{$\begin{array}{l}\text { Patient-related } \\
\text { criteria' }\end{array}$} & $\begin{array}{l}\text { Patient decisional quality: (= } \\
\text { education level; age; patient } \\
\text { satisfaction with care; knowledge of } \\
\text { kidney cancer; decisional conflict; } \\
\text { emotional impact of decision making; } \\
\text { emotional impact of decision making) }\end{array}$ & $\begin{array}{l}\text { Introduce clinical decision } \\
\text { aids to increase patient } \\
\text { involvement and knowledge } \\
\text { about their disease }\end{array}$ & $\begin{array}{l}\text { Will reduce decisional conflict of } \\
\text { the patient and shared decision } \\
\text { making; however, it does not } \\
\text { replace counselling }\end{array}$ & $(1,9,10)$ \\
\hline & $\begin{array}{l}\text { Patient's risk perception: (= fear of } \\
\text { recurrence; fatigue; anxiety; concerns } \\
\text { about cancer; depression; aches; } \\
\text { decreased interest in previously } \\
\text { enjoyed activities; decreased } \\
\text { interest in previously enjoyed events; } \\
\text { decreased interest in previously } \\
\text { enjoyed events; reluctance to start } \\
\text { new relationships) }\end{array}$ & $\begin{array}{l}\text { Providing patients/ } \\
\text { caregivers with an } \\
\text { electronic or written } \\
\text { document to act as a } \\
\text { reminder/resource }\end{array}$ & $\begin{array}{l}\text { Will ensure that physicians do } \\
\text { not omit or 'gloss over' important } \\
\text { issues and patient can access } \\
\text { information provided in a less } \\
\text { stressful environment }\end{array}$ & (8) \\
\hline \multirow[t]{3}{*}{$\begin{array}{l}\text { Patient-physician } \\
\text { interaction }\end{array}$} & \multirow{3}{*}{$\begin{array}{l}\text { Patient involvement in decision } \\
\text { making: (= interaction with different } \\
\text { specialities; perceived shared } \\
\text { decision making; paternalistic care, } \\
\text { (clear) information provided by the } \\
\text { doctor; psychological support) }\end{array}$} & $\begin{array}{l}\text { Interdisciplinary counselling } \\
\text { service }\end{array}$ & $\begin{array}{l}\text { Will enable patient to receive a } \\
\text { complete picture }\end{array}$ & (7) \\
\hline & & $\begin{array}{l}\text { Provide more information } \\
\text { about their cancer, long } \\
\text { term follow-up and potential } \\
\text { complications }\end{array}$ & $\begin{array}{l}\text { Setting the scene for decision } \\
\text { making and setting patient } \\
\text { expectations }\end{array}$ & (8) \\
\hline & & $\begin{array}{l}\text { Shared decision-making } \\
\text { modelling }\end{array}$ & $\begin{array}{l}\text { Consider use in reimbursement } \\
\text { models (US) and private } \\
\text { consultations. Increases adherence } \\
\text { to clinical management guidelines. }\end{array}$ & (1) \\
\hline
\end{tabular}

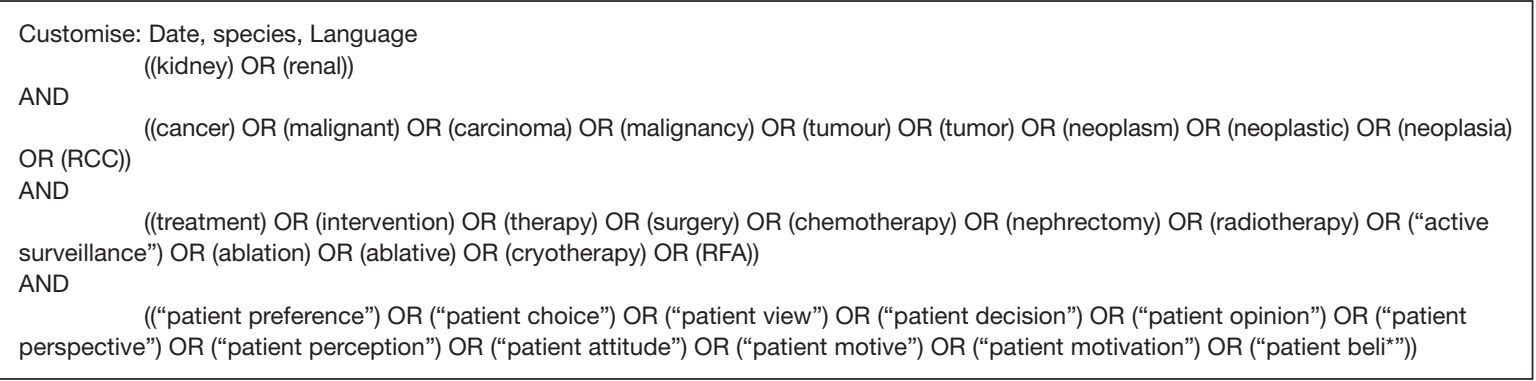

Figure 1 Key word search terms.

(in 2018) and Moretto (in 2014) concluded that patients lack knowledge even after counselling $(1,8)$, and consequently are heavily influenced by paternalistic care (1). To enable the patient to actively participate in their own care, Huber et al. (in 2018) introduced interdisciplinary counselling in which the patient was encouraged to attend the tumour board (i.e., Multi-Disciplinary Team meeting) (7).
This led to a significant shift in treatment decision-making, with documented change in treatment decisions alongside improved satisfaction with care (7). McAlpine et al. (in 2019) developed two patient decision aids for patients with localised renal cancer, which aimed to improve decisional quality $(9,10)$.

This short review captures the complexity of 


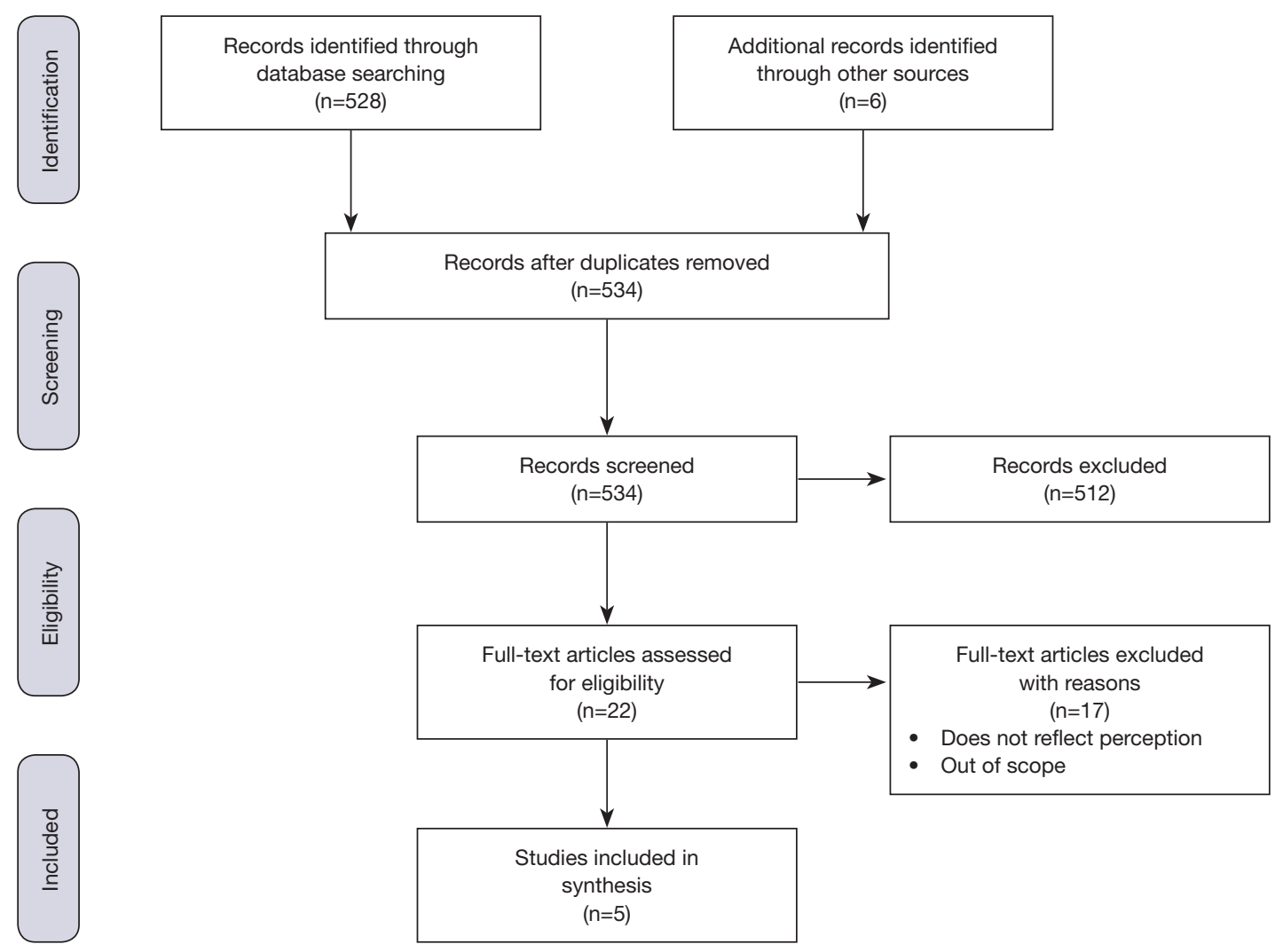

Figure 2 PRISMA.

decision-making purely from the patient perspective. An understanding of these factors is required to reduce paternalistic decision-making models of care and empower patients to take an equal and active part in the treatment decision-making process. However, we recommend future research of all factors influencing the treatment decision making process (e.g., physician-related factors) to increase guideline adherence, improve satisfaction of care and in particularly help to capture the complexity of decision making.

\section{Acknowledgments}

Funding: None.

\section{Footnote}

Provenance and Peer Review: This article was commissioned by the editorial office, Translational Andrology and Urology, for the series "Expectant Management in Genitourinary Malignancies (Prostate, Bladder, Kidney)". The article did not undergo external peer review.

Conflicts of Interest: The authors have completed the ICMJE uniform disclosure form (available at http:// dx.doi.org/10.21037/tau-20-1317). The series "Expectant Management in Genitourinary Malignancies (Prostate, Bladder, Kidney)" was commissioned by the editorial office without any funding or sponsorship. MVH served as the unpaid Guest Editor of the series. KB reports grants from Kidney Cancer UK, during the conduct of the study; other from Royal Marsden Charity, outside the submitted work. RB reports grants from kidney cancer uk, during the conduct of the study. DN reports grants from Kidney Cancer UK, during the conduct of the study. MVH reports grants from KCUK, during the conduct of the study. NK reports grants from KCUK, during the conduct of the study; grants from Kidney Cancer UK, from null, outside the submitted work. The authors have no other conflicts of interest to declare.

Ethical Statement: The authors are accountable for all 
aspects of the work in ensuring that questions related to the accuracy or integrity of any part of the work are appropriately investigated and resolved.

Open Access Statement: This is an Open Access article distributed in accordance with the Creative Commons Attribution-NonCommercial-NoDerivs 4.0 International License (CC BY-NC-ND 4.0), which permits the noncommercial replication and distribution of the article with the strict proviso that no changes or edits are made and the original work is properly cited (including links to both the formal publication through the relevant DOI and the license). See: https://creativecommons.org/licenses/by-nc-nd/4.0/.

\section{References}

1. Shirk JD, Laviana A, Lambrechts S, et al. Decisional Quality in Patients With Small Renal Masses. Urology 2018;116:76-80.

2. Ljungberg B, Albiges L, Abu-Ghanem Y, et al. European Association of Urology Guidelines on Renal Cell Carcinoma: The 2019 Update. Eur Urol 2019;75:799-810.

3. Kazimierczak KA, Skea ZC, Dixon-Woods M, et al. Provision of cancer information as a "support for navigating the knowledge landscape": Findings from a critical interpretive literature synthesis. Eur J Oncol Nurs 2013;17:360-9.

Cite this article as: Beyer K, Barod R, Nicol D, Hussain M, Van Hemelrijck M, Kinsella N. Factors that influence patients' views on treatment decision-making in localised kidney cancer. Transl Androl Urol 2021;10(6):2824-2827. doi: 10.21037/tau-201317
4. Nicol D. Comparison of UK and European Association of Urology (EAU) guidelines for kidney cancer management. J Clin Urol 2017;11:132-8.

5. Moher D, Liberati A, Tetzlaff J, et al. Preferred reporting items for systematic reviews and meta-analyses: the PRISMA statement. PLoS Med 2009;6:e1000097.

6. Pearson A, White H, Bath-Hextall F, et al. Methodology for JBI mixed methods systematic reviews. Available online: https://nursing.lsuhsc.edu/JBI/docs/ReviewersManuals/ Mixed-Methods.pdf

7. Huber J, Ihrig A, Winkler E, et al. Interdisciplinary counseling service for renal malignancies: a patientcentered approach to raise guideline adherence. Urol Oncol 2015;33:23.e1-7.

8. Moretto P, Jewett MA, Basiuk J, et al. Kidney cancer survivorship survey of urologists and survivors: The gap in perceptions of care, but agreement on needs. Can Urol Assoc J 2014;8:190-4.

9. McAlpine K, Breau RH, Stacey D, et al. Development and acceptability testing of a patient decision aid for individuals with localized renal masses considering surgical removal with partial or radical nephrectomy. Urol Oncol 2019;37:811.e1-7.

10. McAlpine K, Breau RH, Stacey D, et al. Shared decisionmaking for the management of small renal masses development and acceptability testing of a novel patient decision aid. Can Urol Assoc J 2020;14:385-91. 